\title{
Effect of Niobium Oxide Phase on the Furfuryl Alcohol Dehydration
}

Xiaojun Chan ${ }^{\mathrm{a}}$, Tiancheng $\mathrm{Pu}^{\mathrm{a}}$, Xianyin Chen ${ }^{\mathrm{b}}$, Alwin James ${ }^{\mathrm{b}}$, Jaeha Lee ${ }^{\mathrm{c}}$, John B. Parise $^{\mathrm{b}}$, Do Heui Kim ${ }^{\mathrm{c}}$, Taejin $\mathrm{Kim}^{\mathrm{a}}{ }^{*}$

${ }^{a}$ Materials Science and Chemical Engineering Department, Stony Brook University, Stony Brook, NY, 11794, USA

${ }^{\mathrm{b}}$ Department of Geoscience, Stony Brook University, Stony Brook, NY, 11794, USA

${ }^{c}$ School of Chemical and Biological Engineering, Institute of Chemical Processes, Seoul National University, Seoul, 151-744, Rep. of Korea

* Corresponding author.

Prof. Taejin Kim

Materials Science and Chemical Engineering Department

Stony Brook University

Stony Brook, NY, 11794, USA

Phone: (+1)631-632-8433

Fax: (+1)631-632-8052

E-mail: taejin.kim@stonybrook.edu 


\begin{abstract}
Different structural phases (e.g., TT, T, and H) of niobium oxide were synthesized, characterized by XRD and Raman, and utilized for the furfuryl alcohol dehydration and condensation under mild conditions $\left(100^{\circ} \mathrm{C}\right.$ and ambient pressure). Furfuryl alcohol conversion was dependent on reaction time and niobium oxide phase. Niobic acid and $\mathrm{T} / \mathrm{H}$ phase transitional niobium oxide showed higher catalytic activity in comparison to a single crystalline phase niobium oxide. While $\mathrm{T} / \mathrm{H}$ phase transitional niobium oxide showed higher conversion than that of niobic acid and TT phase niobium oxide, higher $\mathrm{C}_{9}-\mathrm{C}_{15}$ products' selectivity (> 60\%) was obtained with the latter catalysts.
\end{abstract}

KEYWORDS: Furfuryl Alcohol, Niobic acid, Niobium Oxide Phase, XRD, Raman.

\title{
1. Introduction
}

Lignocellulosic biomass has been considered as an attractive feedstock for fuels and chemicals [1]. One of the attractive chemical products during the lignocellulose conversion reaction is furfuryl alcohol (FA), which is the product obtained by a selective hydrogenation process from furfural [2]. FA has been considered as an important building block for the production of levulinic acid and ethyl levulinate which are platform molecules for the production of liquid hydrocarbon fuels [3]. FA dehydration and condensation reaction into oligomer and polymer have been also extensively investigated because of a wide range of applications, such as nanocomposite carbon, carbon nanotubes, and fuel blending components $[4,5]$. FA oligomers have the capacity to be converted to alkanes using hydrodeoxygenation (HDO) reactions [6]. Recently, Kim et al. investigated furfuryl alcohol dehydration into oligomers using mineral acid (i.e., sulfuric acid) [7]. Nevertheless, the method of using sulfuric acid is not industrially favorable as it is highly corrosive and presents considerable difficulties in separation and recycling after the reaction. Instead, solid acids catalysts have attracted significant attention due to their easiness of separation from product and versatility of surface modification [8]. Metal oxides such as $\mathrm{TiO}_{2}, \mathrm{Al}_{2} \mathrm{O}_{3}$, and $\mathrm{ZrO}_{2}$ have been widely studied as catalysts for dehydration of carbohydrates and simple alcohols [9-11]. In addition to these metal oxides, $\mathrm{Nb}_{2} \mathrm{O}_{5}$ has long been known as its acidic properties and potential to be applied as a solid acid catalyst and a catalyst support [12]. $\mathrm{Nb}_{2} \mathrm{O}_{5}$ compounds generally possess a series of distorted $\mathrm{NbO}_{6}$ octahedral structure where its Lewis and Brønsted acidity are associated with the $\mathrm{Nb}=\mathrm{O}$ and $\mathrm{Nb}-\mathrm{OH}$ bonds, respectively [13]. It also reported that $\mathrm{H}_{2} \mathrm{O}$ coordinated $\mathrm{NbO}_{6}$ (niobic acid, $\mathrm{Nb}_{2} \mathrm{O}_{5} \cdot \mathrm{nH}_{2} \mathrm{O}$ ), containing highly polarized $\mathrm{Nb}-\mathrm{OH}$, shows Brønsted acid character and can be applied to dehydration and hydrolysis reaction $[14,15]$. It has been investigated the phase transformation of $\mathrm{Nb}_{2} \mathrm{O}_{5}$ happens during the thermal treatments process [16]. F. Wang et al. synthesized TT-phase $\mathrm{Nb}_{2} \mathrm{O}_{5}$ with different surface areas $\left(5.7 \mathrm{~m}^{2} / \mathrm{g} \sim 194.1 \mathrm{~m}^{2} / \mathrm{g}\right)$ by calcining niobic acid at temperature ranged from $400^{\circ} \mathrm{C}$ to $700^{\circ} \mathrm{C}$ [17]. C. Guo and Z. Qian reported that calcined niobic acid at $300^{\circ} \mathrm{C}$ shows higher activity for the 2-propanol 
dehydration than untreated niobic acid [18]. Thus, we hypothesize that calcination temperature can be used as a simple yet reliable parameter to modify the properties of the niobium oxides to favor the corresponding catalytic reaction.

In this paper, we describe a number of observations regarding the $\mathrm{Nb}_{2} \mathrm{O}_{5}$ phase effect on FA dehydration activity and products selectivity. The physicochemical properties of these samples are carefully investigated by Raman, XRD, and BET. FA conversion and product selectivity were analyzed by gas chromatography (GC) and GC-mass spectrometry (MS). For comparison, commercial $\mathrm{Nb}_{2} \mathrm{O}_{5}$ also has been investigated.

\section{Experimental sections}

Niobic acid was obtained from CBMM (AD5015HY340). Niobium oxide (99.99\%) and FA (98\%) were obtained from Sigma-Aldrich. $\mathrm{Nb}_{2} \mathrm{O}_{5}$ solid acid catalysts with different surface area were prepared by calcination of niobic acid at various temperature $\left(500-1000^{\circ} \mathrm{C}\right.$ ) in flowing air (Airgas, extra dry) for $2 \mathrm{~h}$ with a ramping rate of $4^{\circ} \mathrm{C} / \mathrm{min}$. Specific surface area and pore size distribution of the catalysts were measured with a Micromeritics ASAP 2010 apparatus at liquid $\mathrm{N}_{2}$ temperature $\left(-196^{\circ} \mathrm{C}\right)$. To determine $\mathrm{Nb}_{2} \mathrm{O}_{5}$ phase identity, powder X-ray diffraction (XRD) data were collected using a Rigaku Ultima-IV diffractometer at ambient conditions using $\mathrm{Cu} \mathrm{K \alpha}(\lambda=1.5418 \AA)$, at a range of $5^{\circ} \leq 2 \theta \leq 60^{\circ}$, with a scanning rate of $0.2 \% \mathrm{~min}$. A quantitative Rietveld analysis was used to determine the phase percentages in the $800^{\circ} \mathrm{C}-1000^{\circ} \mathrm{C}$ calcined and commercial $\mathrm{Nb}_{2} \mathrm{O}_{5}$ (details in the Supporting Information. S.1). The change of $\mathrm{Nb}_{2} \mathrm{O}_{5}$ molecular structure was also determined by Raman spectroscopy (details in the Supporting information. S.2). The batch FA oligomerization experiments were carried out in $7 \mathrm{~mL}$ clean glass vials in an aluminum block covered by heating tape (HTS/Amptek). $3.00 \mathrm{~g} \mathrm{FA}$ and $0.03 \mathrm{~g}$ catalysts were added in vials, and heated to $100^{\circ} \mathrm{C}$ for $2 \mathrm{~h}, 4 \mathrm{~h}$ and $6 \mathrm{~h}$ under constant stirring conditions. After finishing FA dehydration reaction, the glass vials were immediately quenched in an ice water to stop further reaction. After centrifuging, the glass vials were stored properly in the fridge before GC analysis. Compositions and concentrations of products were identified by GC/MS and GC/FID (details in the Supporting information. S.3).

\section{Results and discussion}

It was reported that calcination temperature critically affects the surface area of niobic acid [19]. The BET surface areas of the niobium based catalysts are summarized in Table 1 . The BET surface areas decreased continuously from $130 \mathrm{~m}^{2} / \mathrm{g}$ (niobic acid) to $5 \mathrm{~m}^{2} / \mathrm{g}\left(700^{\circ} \mathrm{C}\right.$ calcined sample) with increasing calcination temperature, due to the formation of $\mathrm{Nb}_{2} \mathrm{O}_{5}$ crystalline structure. For the samples calcined at $\geq 800^{\circ} \mathrm{C}$, the surface area was measured to be less than $1 \mathrm{~m}^{2} / \mathrm{g}$. Pore volume of catalysts followed the same pattern to that of the surface area. Micro-porosity was not observed on any of the investigated catalysts in the present work. Similar surface areas pattern was shown in a previous study [17]. For 
comparison, surface area and pore volume of commercial $\mathrm{Nb}_{2} \mathrm{O}_{5}$ are also shown in Table 1. The commercial $\mathrm{Nb}_{2} \mathrm{O}_{5}$ may possess similar structural properties as $800^{\circ} \mathrm{C}$ $-1000^{\circ} \mathrm{C}$ calcined $\mathrm{Nb}_{2} \mathrm{O}_{5}$ samples, since all of them have similar surface area and pore volume.

The XRD patterns of the niobic acid, $\mathrm{Nb}_{2} \mathrm{O}_{5}$ samples obtained at different calcination temperatures, and commercial $\mathrm{Nb}_{2} \mathrm{O}_{5}$ catalysts are shown in Figure. 1. No diffraction pattern was observed for the niobic acid catalyst indicating that it contains amorphous structure. For $\mathrm{Nb}_{2} \mathrm{O}_{5}\left(500^{\circ} \mathrm{C}\right)$, TT phase peaks were observed at $22.6^{\circ}$, $28.6^{\circ}, 36.8^{\circ}, 46.3^{\circ}, 50.7^{\circ}$, and $55.2^{\circ}[20] . \mathrm{Nb}_{2} \mathrm{O}_{5}\left(600^{\circ} \mathrm{C}\right)$ show similar XRD pattern that of $500^{\circ} \mathrm{C}$, while weak shoulder peak was shown at $28.9^{\circ}$. The XRD pattern of the $700^{\circ} \mathrm{C}$ calcined $\mathrm{Nb}_{2} \mathrm{O}_{5}$ sample shows splitted peaks at $28.9^{\circ}$ and $37.1^{\circ}$ which indicates that TT phase $\mathrm{Nb}_{2} \mathrm{O}_{5}$ was transformed into T phase. Previously, R. Fiz et al. observed similar phase transformation (TT to $\mathrm{T}$ phase) at $500^{\circ} \mathrm{C}$ and pointed out the main difference lies in the broadening of the peaks in the $\mathrm{TT}-\mathrm{Nb}_{2} \mathrm{O}_{5}$, as well as a clear split of the peaks in the more crystalline and lower symmetry of $\mathrm{T}-\mathrm{Nb}_{2} \mathrm{O}_{5}$ [21]. Thus, the $600^{\circ} \mathrm{C}$ calcined $\mathrm{Nb}_{2} \mathrm{O}_{5}$ could be a transition state between TT and $\mathrm{T}$ phase. With the calcination temperature continuously increased, the intensity of the peaks assigned to $\mathrm{T}$ phase become resolved. Further increasing temperature up to $800^{\circ} \mathrm{C}$ lead to the complete formation of $\mathrm{T}$ phase $\mathrm{Nb}_{2} \mathrm{O}_{5}$ [22]. Another transition state between $\mathrm{T}^{-\mathrm{Nb}_{2} \mathrm{O}_{5}}$ and $\mathrm{H}-\mathrm{Nb}_{2} \mathrm{O}_{5}$ phase was observed in the $\mathrm{Nb}_{2} \mathrm{O}_{5}\left(900^{\circ} \mathrm{C}\right) \mathrm{XRD}$ pattern, while the $1000^{\circ} \mathrm{C}$ calcined sample contains $\mathrm{H}$ phase only. It was also observed that the commercial $\mathrm{Nb}_{2} \mathrm{O}_{5}$ contains both $\mathrm{T}$ and $\mathrm{H}$ phase $\mathrm{Nb}_{2} \mathrm{O}_{5}$ although $\mathrm{H}$ phase dominates. Further Rietveld refinement showed $900^{\circ} \mathrm{C} \mathrm{Nb}_{2} \mathrm{O}_{5}$ has $91.3 \% \mathrm{H}$ phase and $8.7 \% \mathrm{~T}$ phase while commercial $\mathrm{Nb}_{2} \mathrm{O}_{5}$ is composed of $24.5 \% \mathrm{H}$ and $75.5 \% \mathrm{~T}$ (Table $\mathrm{S} 1$ ). The obtained XRD spectra proved that $\mathrm{Nb}_{2} \mathrm{O}_{5}$ crystalline phase can be controlled by calcination temperatures. (Table 1)

In addition to the XRD spectroscopy, Raman spectroscopy also provides molecular structural insights into the hydrated (amorphous), dehydrated (crystalline), and different crystalline phases of $\mathrm{Nb}_{2} \mathrm{O}_{5}$ as shown in Figure 2. Niobic acid Raman spectrum shows broad bands at $\sim 262 \mathrm{~cm}^{-1}, \sim 660 \mathrm{~cm}^{-1}$, and $\sim 850 \mathrm{~cm}^{-1}$, which are assigned to $\mathrm{Nb}-\mathrm{O}-\mathrm{Nb}$ bending mode, symmetric stretching mode of the niobia polyhedral, and antisymmetric stretching mode of the $\mathrm{Nb}=\mathrm{O}$ (niobyl) terminal bond in the hydrated state $(\mathrm{Nb}=\mathrm{O}---\mathrm{H})$, respectively [23,24]. J.M. Jehng et al., reported that niobyl band shifted to $\sim 900 \mathrm{~cm}^{-1}$ under dehydration condition at $120^{\circ} \mathrm{C}$. It was also reported that the observed broad Raman bands reflects the distorted $\mathrm{NbO}_{\mathrm{x}}(\mathrm{x}=6,7$, and 8) structures in niobic acid [23-26]. At $500^{\circ} \mathrm{C}-900^{\circ} \mathrm{C}$, the broad Raman band at $\sim 850 \mathrm{~cm}^{-1}$ shifted to $\sim 930 \mathrm{~cm}^{-1}$ and intensity was decreased due to the decreasing of $\mathrm{Nb}=\mathrm{O}$ bond distance and concentrations correspondingly [25]. Symmetric stretching mode of the niobia polyhedral band was shifted from $\sim 685 \mathrm{~cm}^{-1}$ to $\sim 693 \mathrm{~cm}^{-1}$ due to the increased bond order. In addition to the peak shift, full-width half-maximum (FWHM) value was also sharply decreased from $158 \mathrm{~cm}^{-1}\left(\mathrm{Nb}_{2} \mathrm{O}_{5} 500^{\circ} \mathrm{C}\right)$ to $111 \mathrm{~cm}^{-1}$ $\left(\mathrm{Nb}_{2} \mathrm{O}_{5} 900^{\circ} \mathrm{C}\right)$ due to the more ordered crystalline structure. XRD results explained that calcination $\mathrm{Nb}_{2} \mathrm{O}_{5}$ at $\geq 600^{\circ} \mathrm{C}$ leads to a well crystalized $\mathrm{T} / \mathrm{TT}$ phase which is 
reflected by the sharpening of the strong Raman band at $\sim 693 \mathrm{~cm}^{-1}$. The $\geq 600^{\circ} \mathrm{C}$ calcined sample's Raman spectrum also clearly show two $\mathrm{Nb}-\mathrm{O}-\mathrm{Nb}$ bending mode peaks at $\sim 251 \mathrm{~cm}^{-1}$ and $\sim 315 \mathrm{~cm}^{-1}$. XRD and Raman spectra provide that $600-900^{\circ} \mathrm{C}$ calcined $\mathrm{Nb}_{2} \mathrm{O}_{5}$ samples possess both TT and $\mathrm{T}$ phase which are very similar structure, while $\mathrm{Nb}_{2} \mathrm{O}_{5}\left(900^{\circ} \mathrm{C}\right) \mathrm{XRD}$ also shows small $\mathrm{H}-\mathrm{Nb}_{2} \mathrm{O}_{5}$ peaks. For the $\mathrm{Nb}_{2} \mathrm{O}_{5}$ calcined at $1000^{\circ} \mathrm{C}$, multiple new Raman bands were observed, indicating a phase transformation of structure from $\mathrm{T}-\mathrm{Nb}_{2} \mathrm{O}_{5}$ to $\mathrm{H}-\mathrm{Nb}_{2} \mathrm{O}_{5}$. Raman bands at $\sim 901 \mathrm{~cm}^{-1}$ and $\sim 993 \mathrm{~cm}^{-1}$ are assigned to antisymmetric and symmetric stretching modes of the $\mathrm{Nb}=\mathrm{O}$ terminal double bond [24,25,27]. The new Raman bands below $900 \mathrm{~cm}^{-1}$ are assigned to stretching modes of the slightly and highly distorted octahedral $\mathrm{NbO}_{6}$ $\left(\sim 627 \mathrm{~cm}^{-1}\right.$ and $\left.\sim 671 \mathrm{~cm}^{-1}\right)$ and related to a linear $\mathrm{Nb}-\mathrm{O}-\mathrm{Nb}$ bond $\left(\sim 842 \mathrm{~cm}^{-1}\right)$ in the $\mathrm{H}-\mathrm{Nb}_{2} \mathrm{O}_{5}$. Raman bands at $\sim 264 \mathrm{~cm}^{-1}$ and $\sim 306 \mathrm{~cm}^{-1}$ are characteristic of the $\mathrm{Nb}-\mathrm{O}-\mathrm{Nb}$ banding modes in the orthorhombic $\mathrm{Nb}_{2} \mathrm{O}_{5}$ phase. It is also observed that commercial $\mathrm{Nb}_{2} \mathrm{O}_{5}$ Raman spectrum shows similar band position with $\mathrm{Nb}_{2} \mathrm{O}_{5}\left(1000^{\circ} \mathrm{C}\right)$ one, even though previous XRD results showed that commercial $\mathrm{Nb}_{2} \mathrm{O}_{5}$ is a mixture of both $\mathrm{T}$ and $\mathrm{H}$ phase structures.

Figure 3 shows the catalytic performance of various $\mathrm{Nb}_{2} \mathrm{O}_{5}$ samples. As shown in Figure 3(a), niobic acid, TT phase $\left(500^{\circ} \mathrm{C}\right)$ and $\mathrm{T} / \mathrm{H}$ mixed phase $\mathrm{Nb}_{2} \mathrm{O}_{5}\left(900^{\circ} \mathrm{C}\right.$ and commercial) showed higher catalytic activity compared to other single phase crystalline $\mathrm{Nb}_{2} \mathrm{O}_{5}(\mathrm{~T}$ or $\mathrm{H})$. Due to its strong Lewis and Brønsted acidity [14,28], niobic acid (amorphous) presents a higher FA conversion than well crystallized $\mathrm{T}$ or $\mathrm{H}$ phase $\mathrm{Nb}_{2} \mathrm{O}_{5}$. Previously, Shiju et al also found that amorphous $\mathrm{Nb}_{2} \mathrm{O}_{5}$ has better catalytic activity than $\mathrm{T}$ phase $\mathrm{Nb}_{2} \mathrm{O}_{5}$ during the acetalization of glycerol [19]. By using DRIFT spectroscopy with pyridine absorption, they attributed the above activity difference to the decreased Brønsted acid sites in $\mathrm{T}$ phase $\mathrm{Nb}_{2} \mathrm{O}_{5}$. Similarly, S. Chai et al also found the increase in the calcination temperature (up to $700^{\circ} \mathrm{C}$ ) reduced the $\mathrm{Nb}_{2} \mathrm{O}_{5}$ acidity [29]. Since the $>700^{\circ} \mathrm{C}$ calcined $\mathrm{Nb}_{2} \mathrm{O}_{5}$ samples have quite small surface area, it is hard to determine their surface Brønsted and Lewis acidity by a temperature-programmed-desorption process, such as $\mathrm{NH}_{3}$-TPD or pyridine absorption. Previously J.M. Jehng et al, reported that Brønsted acid sites correspond to the slightly distorted $\mathrm{NbO}_{6}, \mathrm{NbO}_{7}, \mathrm{NbO}_{8}$ Raman bands between 500 and $700 \mathrm{~cm}^{-1}$, while the Lewis acid sites are associated with the highly distorted $\mathrm{NbO}_{6}$ Raman bands in the $850-1000 \mathrm{~cm}^{-1}$ region [23]. Figure 2 shows that the intensity of Raman bands in the $850-1000 \mathrm{~cm}^{-1}$ region decreased with elevated calcination temperature up to $900^{\circ} \mathrm{C}$, indicating a decreased Lewis acid sites in $\mathrm{T}$ phase $\mathrm{Nb}_{2} \mathrm{O}_{5}$. Thus, based on Raman spectra, the relative low conversion obtained by $\mathrm{T}$ phase $\mathrm{Nb}_{2} \mathrm{O}_{5}$ could be explained by the decreased Lewis acid sites although it still plays an important role for FA dehydration. However, even though both $\mathrm{T}$ and $\mathrm{H}$ phase $\mathrm{Nb}_{2} \mathrm{O}_{5}$ are not very active during FA dehydration, $\mathrm{T} / \mathrm{H}$ phase transitional $\mathrm{Nb}_{2} \mathrm{O}_{5}$ showed a high conversion rate, comparable with niobic acid. This result provides that FA dehydration was affected by not only acidity, but structure of phase transition. It is also worth noting that the surface area of $\mathrm{Nb}_{2} \mathrm{O}_{5}$ gradually decreased during the amorphous to crystalline transformation. Thus the catalytic performance, for instance conversion $/ \mathrm{nm}^{2}$, of $900^{\circ} \mathrm{C}$ calcined $\mathrm{Nb}_{2} \mathrm{O}_{5}$ could be even better than niobic acid consider the former one has a far 
less surface area. In order to further investigate the double phase effect on the catalytic activity of $900^{\circ} \mathrm{C}$ calcined $\mathrm{Nb}_{2} \mathrm{O}_{5}$, a control experiment was done using $\mathrm{Nb}_{2} \mathrm{O}_{5}$ prepared by physically mixing $800^{\circ} \mathrm{C} \mathrm{Nb}_{2} \mathrm{O}_{5}$ (pure $\mathrm{T}$ ) and $1000^{\circ} \mathrm{C} \mathrm{Nb}_{2} \mathrm{O}_{5}$ (pure $\mathrm{H}$ ) in a ratio of $75.5 / 24.5$. As shown in Figure $\mathrm{S} 2(\mathrm{a})$ left, the control group showed a relative lower conversion rate indicating the transitional structure in the $900^{\circ} \mathrm{C}$ calcined $\mathrm{Nb}_{2} \mathrm{O}_{5}$ plays an important role in boosting its activity. Meanwhile we also observed a similar high activity on Sigma $\mathrm{Nb}_{2} \mathrm{O}_{5}$, which is also a double phase $\mathrm{Nb}_{2} \mathrm{O}_{5}$. Thus a similar control experiment was also done using physically mixed $\mathrm{Nb}_{2} \mathrm{O}_{5}$ composed of $8.7 \% 800^{\circ} \mathrm{C} \mathrm{Nb} 2 \mathrm{O} 5$ (pure $\mathrm{T}$ ) and $91.3 \% 1000^{\circ} \mathrm{C} \mathrm{Nb}_{2} \mathrm{O}_{5}$ (pure $\mathrm{H}$ ). The low conversion rate provided on Figure $\mathrm{S} 2$ (a) right proves that the commercial $\mathrm{Nb}_{2} \mathrm{O}_{5}$ should also possess the T-H transitional structure. In conclusion, the FA conversion rate can be boosted by a T-H transitional structure and it's independent of the phase composition. The FA conversion for all catalysts gradually increases when reaction time increases from $2 \mathrm{~h}$ to $6 \mathrm{~h}$, with the maximum FA conversion rate obtained by $900^{\circ} \mathrm{C}$ calcined $\mathrm{Nb}_{2} \mathrm{O}_{5}$ at $6 \mathrm{~h}$.

FA oligomerization produces multiple dimers and trimers in the range of $\mathrm{C}_{9}-\mathrm{C}_{15}$. Here, we chose the top four high conversion samples and showed their selectivity to $\mathrm{C}_{9}-\mathrm{C}_{15}$ oligomers in Figure 3(b). Among the several dimers and trimers, ether bridge and terminal-OH dimers are dominant products [7]. The proposed reaction mechanisms for these dimer formation are shown in Figure S3 (details in the Supporting information. S4). The highest selectivity rate $(61.4 \%)$ was obtained by niobic acid at $2 \mathrm{~h}$. For niobic acid and $\mathrm{Nb}_{2} \mathrm{O}_{5}\left(500^{\circ} \mathrm{C}\right)$, the selectivity decreased as a function of reaction time, while $\mathrm{Nb}_{2} \mathrm{O}_{5}\left(900^{\circ} \mathrm{C}\right)$ and commercial $\mathrm{Nb}_{2} \mathrm{O}_{5}$ showed that the selectivity rate increased with increasing reaction time. Even though all the four catalysts show the similar high conversion rate, $\mathrm{T} / \mathrm{H}$ phase transitional $\mathrm{Nb}_{2} \mathrm{O}_{5}$ sample was observed to show a relative low selectivity value compared with niobic acid and TT phase $\mathrm{Nb}_{2} \mathrm{O}_{5}$. Meanwhile as shown in Figure $\mathrm{S} 2(\mathrm{~b})$, the selectivity value of the two physically mixed $\mathrm{Nb}_{2} \mathrm{O}_{5}$ are all higher than their corresponding $\mathrm{T} / \mathrm{H}$ phase transitional $\mathrm{Nb}_{2} \mathrm{O}_{5}$. Thus we believe although the $\mathrm{T}-\mathrm{H}$ transitional structure could boost the convers rate, it can possibly limit the selectivity value. It can be deduced that continually increase the reaction time could further increase the selectivity over $\mathrm{T} / \mathrm{H}$ phase mixed $\mathrm{Nb}_{2} \mathrm{O}_{5}$ since their selectivity value continuously increases within the first $6 \mathrm{~h}$. Thus in order to acquire a high yield to $\mathrm{C}_{9}-\mathrm{C}_{15}$ oligomers (1) shorter reaction times for niobic acid and TT phase $\mathrm{Nb}_{2} \mathrm{O}_{5}$ and (2) longer reaction times for $\mathrm{T} \& \mathrm{H}$ phase mixed $\mathrm{Nb}_{2} \mathrm{O}_{5}$ are required.

It has been reported that the $\mathrm{Nb}_{2} \mathrm{O}_{5}$ contains several polymorphic phases [30]. Figure 4 illustrates the different phases of $\mathrm{Nb}_{2} \mathrm{O}_{5}$. In the case of niobic acid and $\mathrm{Nb}_{2} \mathrm{O}_{5}$ $\left(500^{\circ} \mathrm{C}\right)$ sample, the Brønsted acid site and distorted octahedral geometry can be related to the higher FA conversion. Large area hexagonal shape limited the number of active sites on TT-phase $\mathrm{Nb}_{2} \mathrm{O}_{5}\left(500^{\circ} \mathrm{C}\right)$. Large coordination number also limited the affinity to hydroxyl groups, which gives possible explanation to the low activity of TT-phase $\mathrm{Nb}_{2} \mathrm{O}_{5}$. In the case of $\mathrm{Nb}_{2} \mathrm{O}_{5}\left(700^{\circ} \mathrm{C}-1000^{\circ} \mathrm{C}\right)$ and commercial catalysts, the relationship between $\mathrm{Nb}_{2} \mathrm{O}_{5}$ phase and $\mathrm{FA}$ activity is more complicated and still not 
clear, because both $\mathrm{T}\left(700^{\circ} \mathrm{C}\right.$ and $\left.800^{\circ} \mathrm{C}\right)$ and $\mathrm{H}$ phase $\left(1000^{\circ} \mathrm{C}\right) \mathrm{Nb}_{2} \mathrm{O}_{5}$ show lower catalytic activity compare to $\mathrm{T}-\mathrm{H}$ phase transitional $\mathrm{Nb}_{2} \mathrm{O}_{5}\left(900^{\circ} \mathrm{C}\right.$ and commercial). This synergetic phase effect on FA dehydration, especially brought by the T/H transitional structure, is under investigation. We can hypothesize that intrinsic defect sites or the order of polymorphic phase distortion in $\mathrm{T} / \mathrm{H}$ phase transitional structure can possibly improve the $\mathrm{FA}-\mathrm{Nb}_{2} \mathrm{O}_{5}$ interaction.

\section{Conclusions}

In this paper, we investigated the FA oligomerization over different $\mathrm{Nb}_{2} \mathrm{O}_{5}$ phase catalysts prepared by calcination of niobic acid from $500^{\circ} \mathrm{C}$ to $1000^{\circ} \mathrm{C}$. During the calcination, $\mathrm{Nb}_{2} \mathrm{O}_{5}$ showed phase transformations (e.g., amorphous $\rightarrow \mathrm{TT} \rightarrow \mathrm{T} \rightarrow$ $\mathrm{H})$ accompanied by a serious decreasing of surface area and pore volume. It was found that the FA dehydration and condensation reaction was significantly affected by the $\mathrm{Nb}_{2} \mathrm{O}_{5}$ phases and phase transitional structure. The $\mathrm{T} / \mathrm{H}$ phase transitional $\mathrm{Nb}_{2} \mathrm{O}_{5}$ catalyst exhibited higher conversion than single phase catalysts, while its selectivity to $\mathrm{C}_{9}-\mathrm{C}_{15}$ oligomers value was lower than that of niobic acid. The commercial bulk $\mathrm{Nb}_{2} \mathrm{O}_{5}$ was believed to have a similar $\mathrm{T} / \mathrm{H}$ transitional phase due to its similar conversion rate and phase character compared with synthesized $\mathrm{T} / \mathrm{H}$ phase transitional $\mathrm{Nb}_{2} \mathrm{O}_{5}$. Both acid sites and distorted structures during the phase transition were believed to play a vital role during FA oligomerization reaction.

\section{Acknowledgment}

We would like to thank the Advanced Energy Center (AERTC) at the Stony Brook University for providing facility. We acknowledge funding support from the National Science Foundation (NSF-CBET-1546647). 


\section{References}

[1] A. Requejo, S. Peleteiro, A. Rodríguez, G. Garrote, J.C. Parajo, Energy Fuels. 25 (2011) 4803-4810.

[2] J.P. Lange, E. Van der Heide, J. Van Buijtenen, R. Price, ChemSusChem. 5 (2012) $150-166$.

[3] G.M. Gonzalez Maldonado, R.S. Assary, J.A. Dumesic, L.A. Curtiss, Energy Environ. Sci. 5 (2012) 8990-8997.

[4] H. Wang, J. Yao, Ind. Eng. Chem. Res. 45 (2006) 6393-6404.

[5] X.H. Men, Z.Z. Zhang, H.J. Song, K. Wang, W. Jiang, Compos. Sci. Technol. 68 (2008) 1042-1049.

[6] T.M. Jessica, C.M. Stafford, B.D. Vogt, Soft Matter. 8 (2012) 5225-5232.

[7] T. Kim, R.S. Assary, R.E. Pauls, C.L. Marshall, L.A. Curtiss, P.C. Stair, Catal. Commun. 46 (2014) 66-70.

[8] R.J. Gorte, Catal. Lett. 62 (1999) 1-13.

[9] R. Weingarten, G.A. Tompsett, W.C. Conner, G.W. Huber, J. Catal. 279 (2011) 174-182.

[10] T.K. Phung, A. Lagazzo, M.Á.R. Crespo, V.S. Escribanob, G. Busca, J. Catal. 311 (2014) 102-113.

[11] P. Kostestkyy, J. Yu, R.J. Gorte, G. Mpourmpakis, Catal. Sci. Technol. 4 (2014) 3861-3869.

[12] K. Tanabe, Catal. Today. 78 (2003) 65-77.

[13] I. Nowak, Z. Maria, Chem. Rev. 12 (1999) 3603-3624.

[14] K. Nakajima, Y. Baba, R. Noma, M. Kitano, J.N. Kondo, S. Hayashi, M. Hara, J. Am. Chem. Soc. 133 (2011) 4224-4227.

[15] K. Tanabe, S. Okazaki, Appl. Catal., A. 133 (1995) 191-218.

[16] L. Pan, Y. Wang, X. Wang, H. Qu, J. Zhao, Y. Li, A. Gavrilyuk, Phys. Chem. Chem. Phys. 16 (2014) 20828-20833.

[17] F. Wang, H.Z. Wu, C.L. Liu, R.Z. Yang, W.S. Dong, Carbohydr. Res. 368 (2013) 78-83.

[18] C. Guo, Z. Qian, Catal. Today. 16 (1993) 379-385.

[19] G.S. Nair, E. Adrijanto, A. Alsalme, I.V. Kozhevnikov, D.J. Cooke, D.R. Brown, N.R. Shiju, Catal. Sci. Technol. 2 (2012) 1173-1179

[20] G. Agarwal, G. B. Reddy, J. Mater. Sci. - Mater. Electron. 16 (2005) 21-24.

[21] R. Fiz, L. Appel, A. Gutiérrez-Pardo, J. Ramírez-Rico, S. Mathur, ACS Appl. Mater. Interfaces. 8 (2016) 21423-21430.

[22] J. Liu, D. Xue, K. Li, Nanoscale Res. Lett. 6 (2011) 1-8.

[23] J. M. Jehng, I. E. Wachs, Catal. Today 8 (1990) 37-55.

[24] J.M. Jehng, I.E. Wachs, Chem. Mater. 3 (1991) 100-107.

[25] J. M. Jehng, I. E. Wachs, J. Phys. Chem. 95 (1991) 7373-7379.

[26] T. Armaroli, G. Busca, C. Carlini, M. Giuttari, A.M.R. Galletti, G. Sbrana, J. Mol. Catal. A: Chem. 151 (2000) 233-243.

[27] V. Bhide, E. Husson, M. Gasperin, Mater. Res. Bull. 15 (1980) 1339-1344.

[28] P. Carniti, A. Gervasini, S. Biella, A. Auroux, Catal. Today. 118 (2006) 373-378. 
[29] S. Chai, H. Wang, Y. Liang, B. Xu, J. Catal. 250 (2007) 342-349.

[30] Y. Zhao, X. Zhou, L. Ye, S.C.E. Tsang, Nano Rev. 3 (2012) 17631-17641. 


\section{List of Table}

Table 1. Physical properties of the studied $\mathrm{Nb}_{2} \mathrm{O}_{5}$ catalysts.

\section{List of Figures}

Figure 1. X-ray diffraction (XRD) patterns of niobic acid, $500^{\circ} \mathrm{C}-1000^{\circ} \mathrm{C}$ calcined $\mathrm{Nb}_{2} \mathrm{O}_{5}$ and bulk $\mathrm{Nb}_{2} \mathrm{O}_{5}$ obtained from Sigma-Aldrich. (๘) TT phase; ( $\left.\mathbf{v}\right) \mathrm{T}$ phase; $(\bullet) \mathrm{H}$ phase.

Figure 2. Raman spectra of niobic acid, $500^{\circ} \mathrm{C}-1000^{\circ} \mathrm{C}$ calcined $\mathrm{Nb}_{2} \mathrm{O}_{5}$ and bulk $\mathrm{Nb}_{2} \mathrm{O}_{5}$ obtained from Sigma-Aldrich.

Figure 3. Conversion of FA (a) and selectivity to dimers and trimers (b) using niobic acid, $500^{\circ} \mathrm{C}-1000^{\circ} \mathrm{C}$ calcined $\mathrm{Nb}_{2} \mathrm{O}_{5}$ and bulk $\mathrm{Nb}_{2} \mathrm{O}_{5}$ obtained from Sigma-Aldrich. Reaction condition: $\mathrm{FA}=3.00 \mathrm{~g}$, Catalysts $=0.03 \mathrm{~g}$, Temp $=100^{\circ} \mathrm{C}$, Pressure $=$ atmosphere, Time $=2 \mathrm{hrs}$ (orange), $4 \mathrm{hrs}$ (green), 6hrs(blue).

Figure 4. Illustration of $\mathrm{Nb}_{2} \mathrm{O}_{5}$ phases. 
Table 1. Physical properties of the studied $\mathrm{Nb}_{2} \mathrm{O}_{5}$ catalysts.

\begin{tabular}{|c|c|c|c|}
\hline Catalysts & $\begin{array}{c}\text { Surface area } \\
\left(\mathrm{m}^{2 / 8) b}\right.\end{array}$ & $\begin{array}{c}\text { Pore Volume } \\
\left(\mathrm{cm}^{3 / \mathrm{g}) \mathrm{c}}\right.\end{array}$ & $\begin{array}{c}\mathrm{Nb}_{2} \mathrm{O}_{5} \text { crystalline } \\
\text { Phase }^{\mathrm{d}}\end{array}$ \\
\hline Niobic acid & 130 & 0.11 & amorphous \\
\hline $\mathrm{Nb}_{2} \mathrm{O}_{5}\left(500^{\circ} \mathrm{C}\right)$ & 65 & 0.10 & $\mathrm{TT}$ \\
\hline $\mathrm{Nb}_{2} \mathrm{O}_{5}\left(600^{\circ} \mathrm{C}\right)$ & 12 & 0.08 & $\mathrm{TT} \& \mathrm{~T}$ \\
\hline $\mathrm{Nb}_{2} \mathrm{O}_{5}\left(700^{\circ} \mathrm{C}\right)$ & 5 & 0.05 & $\mathrm{~T}$ \\
\hline $\mathrm{Nb}_{2} \mathrm{O}_{5}\left(800^{\circ} \mathrm{C}\right)$ & $<1$ & $<0.01$ & $\mathrm{~T} \& \mathrm{H}$ \\
\hline $\mathrm{Nb}_{2} \mathrm{O}_{5}\left(900^{\circ} \mathrm{C}\right)$ & $<1$ & $<0.01$ & $\mathrm{H}$ \\
\hline $\mathrm{Nb}_{2} \mathrm{O}_{5}\left(1000^{\circ} \mathrm{C}\right)$ & $<1$ & $<0.01$ & $\mathrm{~T} \& \mathrm{H}$ \\
\hline $\mathrm{Sigma}_{\mathrm{N}}$ Aldrich & $<1$ & $<0.01$ & \\
\hline
\end{tabular}

a ( ): Calcination temperatures.

b Surface area determined by BET method. Pretreatment: $250{ }^{\circ} \mathrm{C}$ for $6 \mathrm{hrs}$, under vacuum conditions.

c Pore Volume determined by BJH method. Pore volume with pore diameter less than $70 \mathrm{~nm}$ is reported.

d Crystalline phase determined by XRD. 


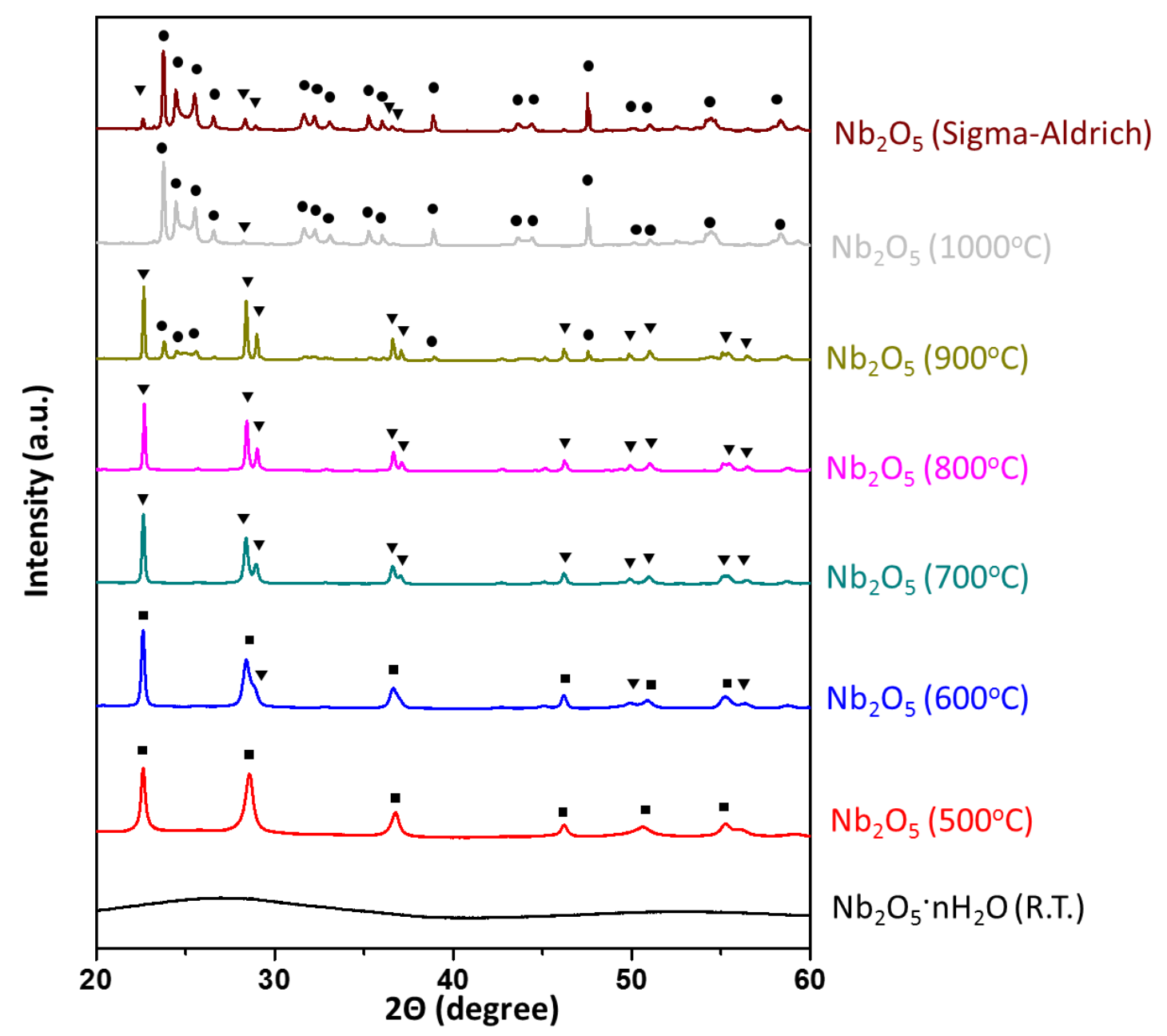

Figure 1. X-ray diffraction (XRD) patterns of niobic acid, $500^{\circ} \mathrm{C}-1000^{\circ} \mathrm{C}$ calcined $\mathrm{Nb}_{2} \mathrm{O}_{5}$ and bulk $\mathrm{Nb}_{2} \mathrm{O}_{5}$ obtained from Sigma-Aldrich. (๘) TT phase; ( $\left.\mathbf{v}\right) \mathrm{T}$ phase; $(\bullet) \mathrm{H}$ phase. 


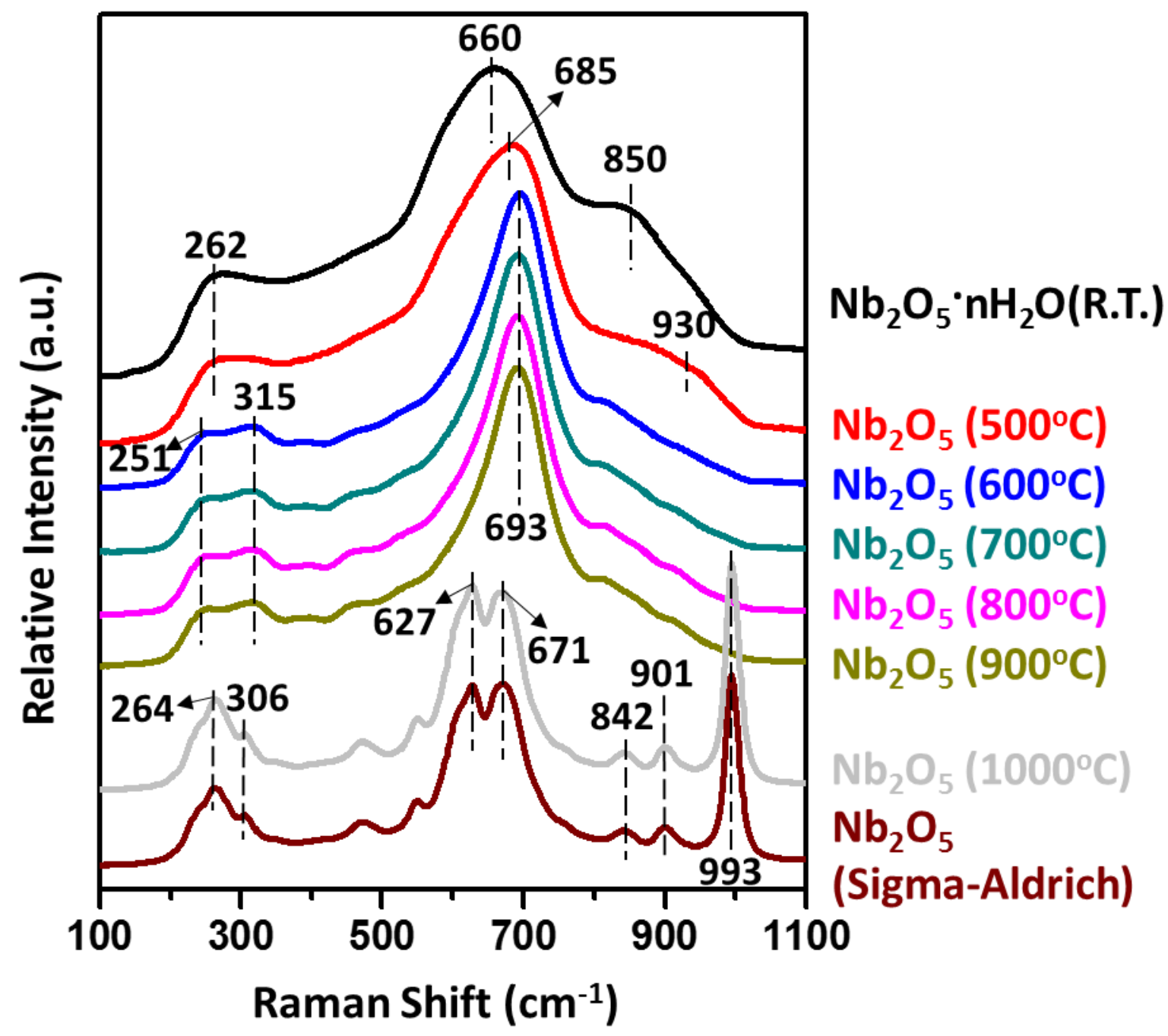

Figure 2. Raman spectra of Niobic acid, $500^{\circ} \mathrm{C}-1000^{\circ} \mathrm{C}$ calcined $\mathrm{Nb}_{2} \mathrm{O}_{5}$ and bulk $\mathrm{Nb}_{2} \mathrm{O}_{5}$ obtained from Sigma-Aldrich. 
(a)

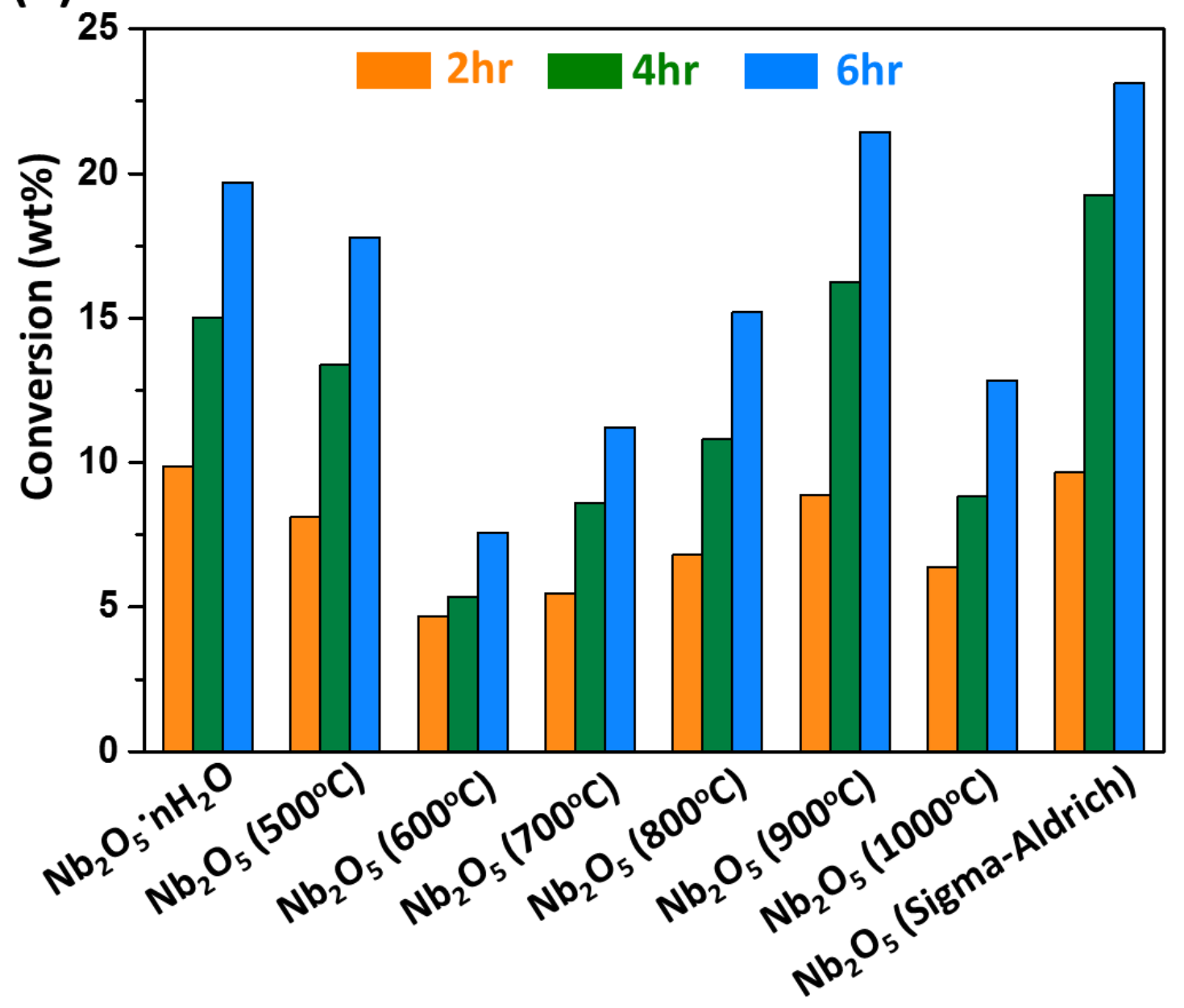




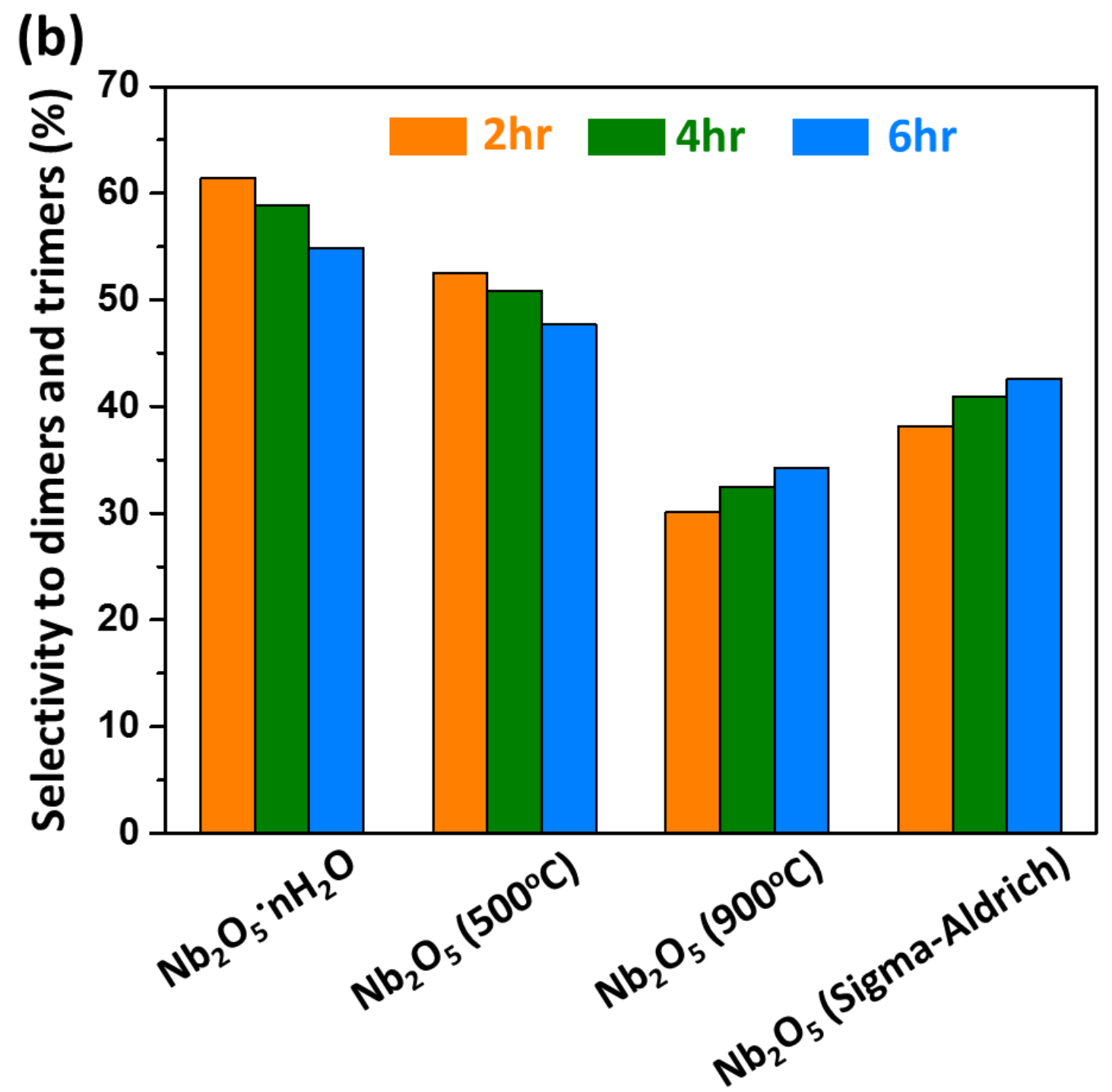

Figure 3. Conversion of FA (a) and selectivity to dimers and trimers (b) using niobic acid, $500^{\circ} \mathrm{C}-1000^{\circ} \mathrm{C}$ calcined $\mathrm{Nb}_{2} \mathrm{O}_{5}$ and bulk $\mathrm{Nb}_{2} \mathrm{O}_{5}$ obtained from Sigma-Aldrich. Reaction condition: $\mathrm{FA}=3.00 \mathrm{~g}$, Catalysts $=0.03 \mathrm{~g}$, Temp $=100^{\circ} \mathrm{C}$, Pressure $=$ atmosphere, Time $=2 \mathrm{hrs}$ (orange), $4 \mathrm{hrs}$ (green), 6hrs(blue). 
Niobic acid $\left(\mathrm{Nb}_{2} \mathrm{O}_{5} \mathrm{H}_{2} \mathrm{O}\right)$

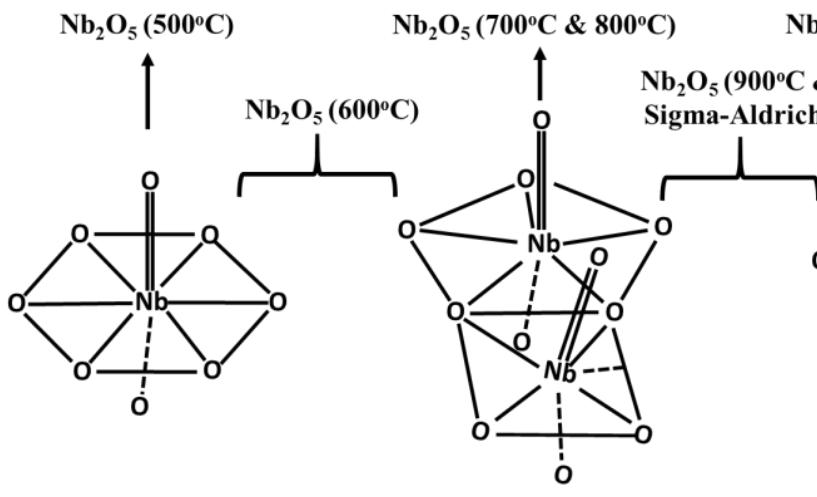

$\mathrm{Nb}_{2} \mathrm{O}_{5}\left(1000^{\circ} \mathrm{C}\right)$

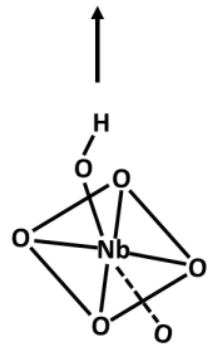

TT phase (pseudo-hexagonal)

$T$ phase (distorted octahedral or $\mathrm{Nb}_{2} \mathrm{O}_{5}$ pentagonal bypyramids) $\mathrm{Nb}_{2} \mathrm{O}_{5}$

H phase (distorted Amorphous (distorted octahedral) $\mathrm{Nb}_{2} \mathrm{O}_{5}$

Figure 4. Illustration of $\mathrm{Nb}_{2} \mathrm{O}_{5}$ phases. 
Graphical abstract

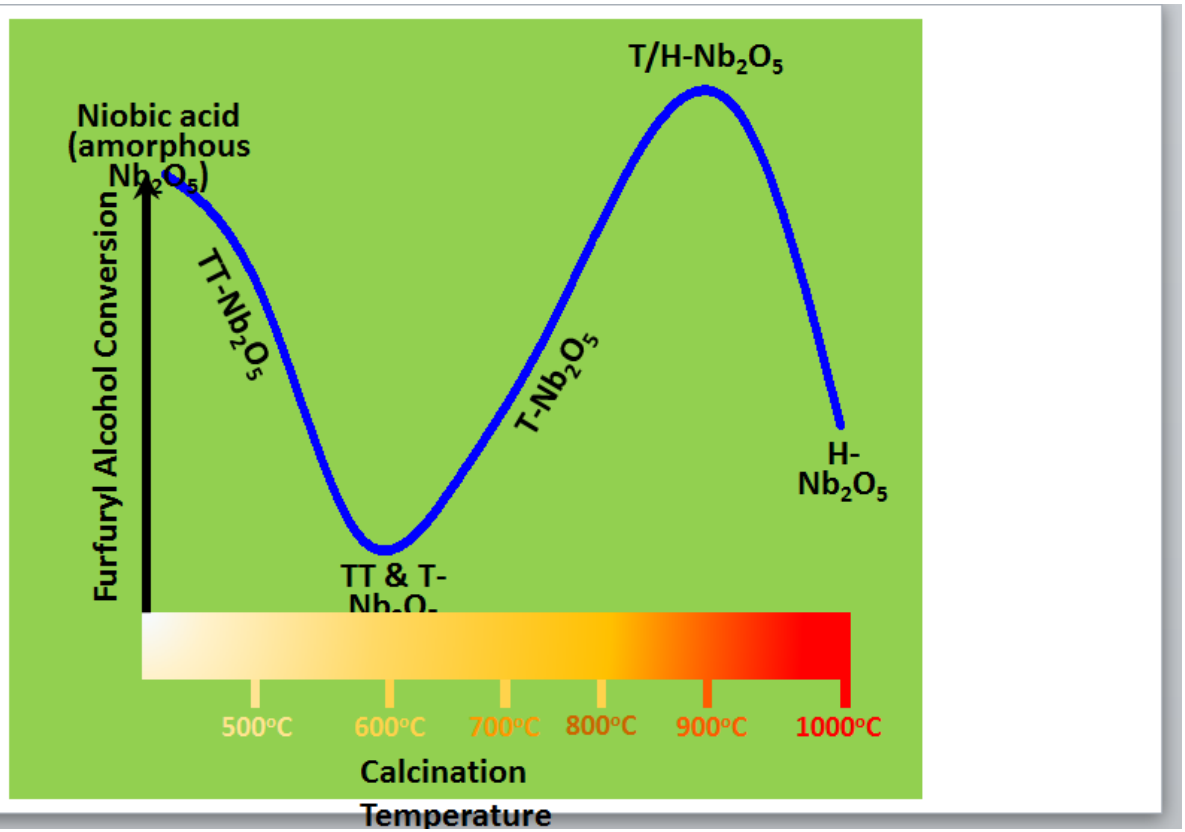

